\title{
Itajaí, Santa Catarina - Azorean ancestry and spinocerebellar ataxia type 3
}

\author{
Itajaí, Santa Catarina - descendência açoriana e ataxia espinocerebelar tipo 3 \\ Hélio A. G. Teive1, Adriana Moro', Walter O. Arruda', Salmo Raskin², Gladys M. G. Teive, Norberto Dallabrida, \\ Renato P. Munhoz ${ }^{4}$
}

\begin{abstract}
The authors present a historical review of spinocerebellar ataxia type 3/Machado-Joseph disease (SCA3/MJD), the most common form of spinocerebellar ataxia in Brazil, and consider the high frequency of cases in families from Itajaí, a city on the coast of the state of Santa Catarina with a large population of Portuguese/Azorean descent.
\end{abstract}

Keywords: spinocerebellar ataxias; Machado-Joseph disease.

\section{RESUMO}

Os autores apresentam uma revisão histórica sobre a ataxia spinocerebelar tipo 3/doença de Machado-Joseph (SCA3/DMJ), que representa a forma de SCA mais comum em nosso país, considerando a alta frequência de casos oriundos de famílias da cidade de Itajaí, no litoral de Santa Catarina, cidade com ascendência portuguesa-açoriana.

Palavras-chave: ataxias espinocerebelares; doença de Machado-Joseph.

Inherited cerebellar ataxias constitute an extensive group of clinically and genetically heterogeneous complex neurodegenerative disorders caused by a large number of genetic mutations ${ }^{1,2}$. They include autosomal dominant cerebellar ataxias, or spinocerebellar ataxias (SCAs), which are characterized by progressive degeneration of the cerebellum and its afferent and efferent connections ${ }^{1,2}$. Spinocerebellar ataxia type 3 (SCA3), or Machado-Joseph disease (MJD), is the most common autosomal dominant cerebellar ataxia worldwide and is particularly common in Brazil ${ }^{1,2,3}$. The first description of MJD was by Coutinho and Andrade in 1978, who studied 40 patients in 15 families from the Azores ${ }^{4}$. A new genetic disorder with an autosomal dominant pattern involving cerebellar, pyramidal, extrapyramidal and spinal cord motor functions was defined. ${ }^{4}$ In the late 1980s, the eponym Machado-Joseph disease was suggested, but the disease subsequently became universally known as SCA $3^{1,2,3}$. The condition shows remarkable clinical heterogeneity, reflecting the underlying genetic defect, an unstable CAG trinucleotide repeat expansion in the SCA3 gene that varies in size among affected patients.
Clinical manifestations include cerebellar ataxia, particularly gait ataxia, bulging eyes, dysarthria, pyramidal signs, progressive ophthalmoplegia, dystonia, parkinsonism, lower motor neuron disease and peripheral neuropathy, with fasciculations and amyotrophy $y^{1,2,3,4,5}$. In Brazil, several studies have focused on the prevalence and clinical presentation of this neurodegenerative disease in different areas, particularly in the south of the country ${ }^{2,3,5}$. Here we discuss the historical importance of the city of Itajaí, in the state of Santa Catarina, as the origin of most cases of SCA3 families in Brazil.

\section{ITAJAÍ, SANTA CATARINA, AND ITS AZOREAN ANCESTRY}

The city of Itajaí, located on the banks of the Itajaí-Açú River on the northern coast of the state of Santa Catarina in the south of Brazil (Figure), has a population of approximately 200,000 inhabitants. Between 1748 and 1756, Santa Catarina received a large contingent of Portuguese immigrants from

\footnotetext{
`Universidade Federal do Paraná, Hospital de Clínicas, Departamento de Medicina Interna, Serviço de Neurologia, Unidade de Distúrbios do Movimento, Curitiba PR, Brasil;

${ }^{2}$ Laboratório Genetika, Curitiba PR, Brasil;

${ }^{3}$ Universidade Estadual de Santa Catarina, Centro de Ciências Humanas e Educação, Florianópolis SC, Brasil;

4 University of Toronto, Toronto Western Hospital, Movement Disorders Centre, Ontário ON, Canada.

Correspondence: Hélio A. G. Teive; Rua General Carneiro 1103/102; 80060-150 Curitiba PR, Brasil; E-mail: hagteive@mps.com.br

Conflict of interest: There is no conflict of interest to declare.

Received 15 May 2016; Accepted 13 June 2016.
} 
the island of Madeira and the nine islands of the Azores. ${ }^{6}$ The islands' serious economic difficulties and the constant seismic activity in the region were the driving factors behind the emigration to Brazil and the state of Santa Catarina in particular. ${ }^{6}$ The Azorean immigrants settled along the coast of the state in an area including Laguna, Enseada de Brito, Santa Catarina Island (Nossa Senhora do Desterro, now known as Florianópolis), São José and São Miguel ${ }^{6}$. While some of the Azoreans who remained on Santa Catarina Island later moved to other regions, including the city of Porto Alegre in the state of Rio Grande do Sul, others subsequently moved to different areas of Santa Catarina and colonized the cities of Itajaí and São Francisco do Sul, which have to this day a strong Azorean ethnic and cultural influence ${ }^{6}$.

\section{MACHADO-JOSEPH'S DISEASE - THE FIRST FAMILY CASE REPORT PUBLISHED IN BRAZIL}

In 1991, Teive et al. published the first report on SCA3/MJD in Brazil. They described clinical and laboratory findings for five members of a family whose diagnosis was later confirmed by molecular tests that revealed four different subphenotypes (1, 2, 3 and 4) $)^{7,8}$. The family was living in Florianópolis, Santa Catarina, where there are many Portuguese descendants from the Azores. One ancestor of this family came from the Azores, and some other members of the family, who were not evaluated at the time, were living in Itajaí, Santa Catarina?.

\section{THE "CATARINA" KINDRED}

In 1988, Radvany et al. studied the first two Brazilian families with a clinical diagnosis of SCA3/MJD, and in 1993, the same authors published a study on the condition in a large family of Azorean descent in the city of Itajaí, in Santa Catarina, that came to be known as the "Catarina kindred" 5,9 . At the time, this family was considered one of the largest families in the world with SCA3/MJD, and the family tree consisted of 622 individuals distributed over nine generations ${ }^{9}$. The authors examined 236 of the 622 individuals and found 39 affected by the disease ${ }^{9}$. The Catarina kindred, so called because the family came from Santa Catarina Island, were descendants of Manoel Antonio Vieira, the son of immigrants from the Azores who arrived in Brazil in the $19^{\text {th }}$

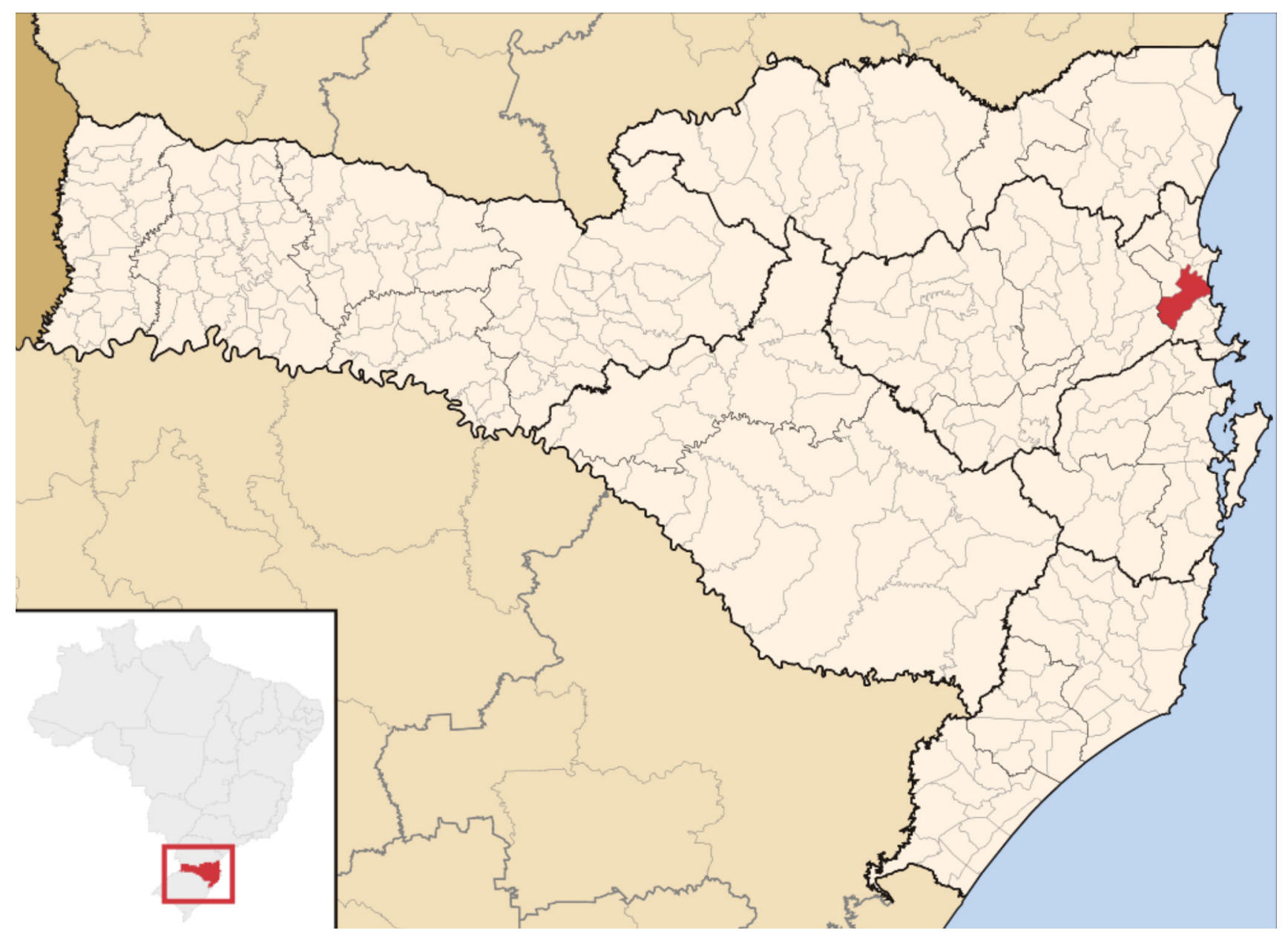

(Extracted from Wikipedia - https://pt.wikipedia.org/wiki/itajai, March, 20 ${ }^{\text {th }}, 2016$ ).

Figure. The city of Itajaí, in the state of Santa Catarina. 
century and were probably related to a family by the surname of Machado9. This Azorean family with SCA3/MJD may have given rise to the phenomenon known as the founder effect in this region of the state of Santa Catarina.

\section{SCA3/MJD IN THE STATES OF PARANÁ AND SANTA CATARINA}

Two hundred and ten families with SCA have been examined at the ataxias outpatient unit in the Hospital de Clínicas, Federal University of Paraná, over the last 27 years, and two thirds of these were diagnosed clinically, with subsequent genetic confirmation. SCA3/MJD is the most common form of ataxia among these patients, accounting for 100 families and 225 patients, i.e., $75 \%$ of the SCA population studied to date (HT, data not yet published). Analysis of the demographic data for these families with SCA3/MJD shows that most of them were originally from the coastal region of the state of Santa Catarina, particularly the city of Itajaí. Although a few patients with SCA3/MJD are from the city of Paranaguá, in the state of Paraná, detailed analysis of these families shows that most of them originally come from the city of Itajaí, in the state of Santa Catarina, lending credence to the hypothesis of a so-called founder effect in the region. Comparison of the significant number of families with SCA3/MJD from this region, with the findings of studies of other Brazilian series, shows the importance of these historical data and suggests that Itajaí has one of the highest frequencies of this form of SCA in Brazil. The second most common form of SCA in the states of Paraná and Santa Catarina is SCA10, which originated in Amerindians, and a founder effect for this form of the disease may have occurred in the population in the town of Ilhota, close to Itajaí $^{10}$.

\section{FINAL REMARKS}

SCA3/MJD is considered the commonest form of SCA in Brazil and has a particularly high prevalence in the states of Santa Catarina and Paraná. Various articles on SCA3/MJD in Brazil that include historical data related to Azorean immigration to the Santa Catarina coast indicate that the city of Itajaí, in Santa Catarina, has one of the highest numbers of families with this heredodegenerative disease, suggesting that this high prevalence may be the result of a founder effect.

\section{Acknowledgement}

The authors are grateful to the late Dr. Estevão Demétrio Nascimento, a neurologist from Itajaí, Santa Catarina, who was involved in the first clinical studies about SCA3.

\section{References}

1. Teive HAG, Ashizawa T. Primary and secondary ataxias. Curr Opin Neurol. 2015;28(4):413-22. doi:10.1097/WC0.0000000000000227

2. Teive HAG. Spinocerebellar ataxias. Arq Neuropsiquiatr. 2009;67(4):1133-42. doi: 10.1590/S0004-282X2009000600035

3. Teive HAG, Munhoz RP, Arruda WO, Lopes-Cendes I, Raskin S, Werneck LC et al. Spinocerebellar ataxias: genotype-phenotype correlations in 104 Brazilian families. Clinics (Sao Paulo). 2012;67(5):443-9. doi:10.6061/clinics/2012(05)07

4. Coutinho P, Andrade C. Autosomal dominant system degeneration in Portuguese families of the Azores islands: a new genetic disorder involving cerebellar, pyramidal, extrapyramidal and spinal cord motor functions. Neurology. 1978;28(7):703-9.

5. Pedroso JL, Braga-Neto P, Radvany J, Barsottini OG. Machado-Joseph disease in Brazil: from the first descriptions to the emergence as the most common spinocerebellar ataxia. Arq Neuropsiquiatr. 2012;70(8):630-2. doi:10.1590/S0004-282X2012000800013

6. Piazza WF, Hubener LM. Santa Catarina: história da gente. 2a ed. Florianópolis: Lunardelli; 1987.
7. Teive HAG, Arruda WO, Trevisol-Bittencourt PC. [MachadoJoseph disease: report on five members of a family]. Arq Neuropsiquiatr. 1991;49(2):172-9. Portuguese. doi:10.1590/S0004-282X1991000200010

8. Moro A, Munhoz RP, Arruda WO, Raskin S, Moscovich M, Teive HAG. Spinocerebellar ataxia type 3: subphenotypes in a cohort of Brazilian patients. Arq Neuropsiquiatr. 2014;72(9):659-62. doi:10.1590/0004-282X20140129

9. Radvany J, Camargo CH, Costa ZM, Fonseca NC, Nascimento ED. Machado-Joseph disease of azorean ancestry in Brazil: the Catarina kindred Neurological, neuroimaging, psychiatric and neuropsychological findings in the largest known family, the "Catarina" kindred. Arq Neuropsiquiatr. 1993;51(1):21-30. doi:10.1590/S0004-282X1993000100004

10. Teive HAG, Moro A, Moscovich M, Arruda WO, Munhoz RP, Raskin S et al. Spinocerebellar ataxia type 10 in the South of Brazil: the Amerindian-Belgian connection. Arq Neuropsiquiatr. 2015;73(8): 725-7. doi:10.1590/0004-282X20150086 


\section{Erratum}

Itajaí, Santa Catarina - Azorean ancestry and spinocerebellar ataxia type 3

Arq Neuropsiquiatr 2016;74(10):858-860. DOI: http://dx.doi.org/10.1590/0004-282X20160125

The name of $6^{\text {th }}$ the author:

Norberto Dalabrida

Should be:

Norberto Dallabrida 